\title{
PERANCANGAN KOMIK 360 SEBAGAI MEDIA INFORMASI TENTANG PELECEHAN SEKSUAL CAT CALLING
}

\author{
Benedicta Alodia Santoso ${ }^{1}$, Michael Bezaleel ${ }^{2}$ \\ ${ }^{1,2}$ Program Studi Desain Komunikasi Visual, Fakultas Teknologi Informasi, \\ Universitas Kristen Satya Wacana \\ 692013051@student.uksw.edu ${ }^{1}$, michael.bezaleel@staff.uksw.edu²
}

\begin{abstract}
Abstrak
Perancangan komik 360 sebagai media informasi tentang pelecehan seksual "cat calling" bertujuan untuk menyampaikan informasi kepada masyarakat tentang isu pelecehan seksual secara verbal berupa cat calling serta bertujuan untuk meningkatkan kepekaan masyarakat tentang kejadian yang dihadapi oleh perempuan di jalanan serta tempat umum berkaitan dengan isu ini. Adapun yang menjadi latar belakang tulisan ini adalah karena tingginya tingkat pelecehan seksual secara verbal yang dialami oleh perempuan, sehingga dibutuhkan sebuah media informasi yang dapat memberi informasi dan gambaran tentang isu ini sehingga kesadaran masyarakat dapat meningkat. Komik 360 pada penelitian ini menggabungkan teknologi virtual reality dengan format video 360 dan gaya gambar komik, sehingga dapat menjadi media informasi yang menarik untuk menyajikan realitas yang dihadapi oleh perempuan dalam kesehariannya menggunakan fasilitas umum. Perancangan ini diharapkan dapat meningkatkan kepekaan masyarakat berkaitan dengan isu ini sehingga di masa depan perempuan dapat merasa lebih aman dan terhindar dari pelecehan seksual cat calling di jalan maupun fasilitas umum. Hasil dari penelitian ini menunjukan bahwa hasil perancangan dapat dijadikan sebagai salah satu media informasi tentang pelecehan seksual cat calling.
\end{abstract}

Kata Kunci: cat calling, komik 360, seksual

\begin{abstract}
The aims of 360 Comic as a medium of information for cat calling sexual harassment are to convey information to the public about verbal sexual abuse issue and increasing public sensitivity about the incidents that happens to women in streets and public places. The background of this study is due to the high level of verbal sexual abuse that is experienced by women. There should be a media that can provide information about this issue to increase public awareness. 360 Comic in this research combined 360 virtual reality video format and comic images style. This research can be an interesting media to present the reality that women faced in their daily activities at public facilities. This research is expected to increase the public awareness and women safety in street and public space. Result of the research shows that the comic 360 is able to become an information media about cat calling.
\end{abstract}

Keywords: cat calling, 360 comic, sexual 


\section{PENDAHULUAN}

\subsection{Pelecehan Seksual Cat Calling}

Perhatian publik terhadap kekerasan dan kesetaraan gender telah menjadi bahasan sejak lama. Banyak usaha dan upaya untuk menjajarkan posisi perempuan dalam kehidupan sosial telah lama diusahakan, namun ditemukan bahwa perempuan masih menjadi masyarakat kelas dua dan sering mengalami diskriminasi serta menjadi sasaran kebencian. Analisis gender menemukan bahwa sebagian perempuan mengalami subordinasi, marginalisasi, dominasi, dan bahkan kekerasan. Hasil penelitian menunjukkan bahwa sekitar $90 \%$ perempuan pernah mengalami kekerasan di wilayah publik (Wattie, 2002).

Kekerasan yang diterima oleh perempuan salah satunya adalah pelecehan seksual. Walaupun korban pelecehan seksual tidak selalu adalah perempuan dan pelaku selalu adalah laki-laki, namun jumlah dan proporsi dimana laki-laki sebagai korban pelecehan seksual oleh perempuan terlalu kecil jika dibanding dengan jumlah korban pelecehan seksual perempuan oleh laki-laki. Sebagian besar korban adalah perempuan dan pelaku adalah laki-laki (Offerman \& Malamut, 2002). Dalam penelitian tentang kekerasan seksual dan simbolis yang mengambil studi kasus di Jakarta, terdapat upaya yang dapat dilakukan demi mencapai tatanan masyarakat yang humanis, salah satunya dengan mengampanyekan perang melawan kekerasan seksual. Masyarakat dapat membantu membuat perubahan dengan cara peka terhadap kasus pelecehan yang terjadi di ruang publik, menjadi pengawas dan memberikan koreksi saat menjadi saksi mata tindakan kejadian pelecehan.

Salah satu bentuk kekerasan seksual yang dialami oleh wanita di ruang publik adalah Cat Calling. Cat calling adalah istilah yang merujuk pada tindakan bernuansa seksual yang disampaikan melalui kontak fisik maupun non fisik yang menyasar pada bagian tubuh seksual atau seksualitas seseorang, termasuk dengan menggunakan siulan, main mata, komentar atau ucapan bernuansa seksual, mempertunjukan materi-materi pornografi dan keinginan seksual, colekan atau sentuhan di bagian tubuh, gerakan atau isyarat yang bersifat seksual sehingga mengakibatkan rasa tidak nyaman, tersinggung merasa direndahkan martabatnya, dan mungkin sampai menyebabkan masalah kesehatan dan keselamatan (Komnas Perempuan, 2013).

\subsection{Gerakan Sosial dan Kampanye Sosial tentang Pelecehan Seksual}

Gerakan sosial yang dilakukan demi menaikkan kesadaran masyarakat tentang isu pelecehan seksual telah lama dilakukan di berbagai negara. Salah satunya adalah gerakan yang tercetus karena kejadian Black Wednesday di Mesir (Schiemer, 2015). Kejadian ini menjadi katalis sebuah gerakan sosial yang menginspirasi banyak negara untuk turut berpartispasi dan membuat gerakan serupa. Di Indonesia, Women's Merch pertama diadakan pada 8 Maret 2017 di Jakarta (Tempo.co, 2017). Sekitar 1.000 orang dengan pakaian berwarna merah jambu dan ungu berjalan menuju Istana Kepresidenan menuntut hak perempuan dan kesenjangan gender, serta untuk meningkatkan kesadaran masyarakat terhadap isu pelecehan seksual. Selain gerakan sosial dengan turun di jalan, gerakan sosial yang dilakukan melalui media sosial telah 
dilakukan sebelumnya dan terbukti efektif. Gerakan kampanye menggunakan media sosial memang cukup ampuh dilakukan. Penelitian yang dilakukan menunjukan bahwa kampanye gerakan sosial menggunakan media sosial lebih mudah disampaikan dan memudahkan interaksi antara penggagas kampanye dan pengguna media social (Kapriani dan Lubis, 2014).

Kampanye untuk meningkatkan kesadaran tentang isu cat calling pernah dilakukan sebelumnya dengan memanfaatkan media video dan disebarkan melalui media sosial yaitu Youtube dan menjadi viral. Video tersebut berjudul Walking in NYC as a Woman. Video tersebut menampilkan potongan-potongan kejadian seorang perempuan yang diklaim berjalan selama 10 jam di jalanan Manhattan dan mengalami pelecehan seksual secara verbal berupa cat calling sebanyak 100 kali.

Video tersebut dengan cepat menjadi populer. Namun pada 2015, aktris yang muncul dalam video tersebut yaitu Shosana Roberts, mengajukan tuntutan terhadap pembuat film tersebut. Dalam tuntutannya, Roberts berargumen bahwa tidak ada perjanjian tertulis yang mengijinkan video tersebut untuk publikasikan secara luas. Akibat dari publikasi video tersebut Roberts menerima berbagai ancaman kekerasan dan pemerkosaan. Selain itu, pembuat film ini juga dianggap bias saat mengedit video karena lebih banyak menampilkan orang latin dan orang kulit hitam yang melakukan pelecehan seksual terhadap wanita dibandingkan orang kulit putih (Dailymail.com Reporter, 2015). Berdasarkan kasus Roberts, media video yang menjadi viral dengan menampilkan seseorang yang benar-benar ada sebagai objek memiliki dampak yang buruk terhadap orang tersebut. Ancaman terhadap keselamatan orang di dalam video dapat melukai orang tersebut baik secara fisik maupun mental. Untuk itu, dibutuhkan sebuah media yang tidak melibatkan identitas orang sesungguhnya, namun dapat memberikan gambaran yang jelas akan kejadian dan trauma korban cat calling sehingga mampu menginformasikan dan mengajak masyarakat untuk tidak mentolerir tindakan cat calling.

\subsection{Komik sebagai Media Kritik Sosial}

Komik merupakan media yang dapat digunakan sebagai sarana untuk menyampaikan pesan. Komik memiliki celah untuk memasukkan peran tanpa memberikan identitas seseorang. Komik adalah sebuah bentuk seni yang menggunakan serangkaian pencitraan yang statis dalam kejadian-kejadian yang di tetapkan. Teks tertulis ini sering kali berkesinambungan. Menurut McCloud (2001), komik adalah gambar yang saling berkaitan dan pencitraan karakter yang saling berhubungan dan bertujuan untuk menyampaikan informasi pada pembaca. Laksono (2004) dalam penelitiannya yang berjudul Comic Strips: Media Kritik Sosial menyatakan bahwa komik merupakan bagian dari popular culture yang memberikan kesenangan bagi pembacanya. Dengan demikian fungsi komik sebenarnya lebih jauh lagi dapat menjadi sarana yang efektif untuk menyampaikan kritik terhadap otoritas maupun perubahan nilai-nilai yang ada di masyarakat. Pesan-pesan yang disampaikan kepada pembaca melalui simbol merupakan salah satu cara pembelajaran bagi masyarakat agar semakin peka dalam menanggapi kondisi sosialnya. Sedangkan dalam bidang edukasi dan pedagogi, Johana 
dan Widiyanti (2007) menyatakan bahwa dalam komik dapat lebih mudah dipahami dan sangat efektif sebagai media pembelajaran. Komik juga digunakan secara eksplisit sebagai media kampanye sosial seperti kampanye safety riding (Saputro, Haryadi, \& Yanuarsari, 2016). Komik dapat menjadi sebuah sarana yang menghibur, media edukasi, pemberi informasi, dan pesan untuk diserap serta menjadi sebuah kritik terhadap isu sosial.

\subsection{Komik 360 Memberi Kesan yang Lebih Nyata}

Untuk dapat memperoleh kesan yang lebih nyata, komik dapat dipadukan dengan teknologi video 360 . Video 360 yang telah ada merupakan teknologi yang berkaitan dengan format video. Berbeda dengan format yang telah ada sebelumnya, format 360 memungkinkan kemungkinan untuk melihat jangkauan vdeo dari seluruh sisi. Format 360 ini disebut juga sebagai spherical video atau video yang berbentuk bola (Etherington, 2015). Format 360 ini dibuat dengan cara mengambil setiap arah secara bersamaan menggunakan beberapa kamera atau omnidirectional camera sehingga penonton dapat mengontrol sisi yang ingin dilihat seperti gambar panorama. Komik 360 adalah sebuah media baru yang menggabungkan cerita bergambar dan teknologi virtual reality. Qubicle (2016) memberitakan bahwa komik 360 diperkenalkan pada kegiatan Popcon Asia 2016 bersamaan dengan peluncuran komik serial anak-anak yang berjudul Angkringan Malioboro. Komik 360 ini menampilkan beberapa tokoh legendaris Indonesia seperti Ir. Soekarno dan Chairil Anwar yang sedang berbincang di sebuah angkringan. Komik 360 dapat dinikmati menggunakan sebuah headpiece khusus untuk menayangkan gambar sehingga penikmat seakan-akan berada di dalam komik. Penikmat bisa menoleh, menengadah, dan menunduk untuk melihat seluruh bagian komik, dan memiliki kebebesan untuk menentukan alur baca. Gabungan dari media komik dengan format video 360 akan menghasilkan media yang baru, yaitu komik 360, dimana gambar statis komik yang saling berkaitan disajikan secara panorama sehingga penikmat dapat seolah-olah berada di dalam dunia komik dan melihat media dalam perspektif orang pertama.

Berdasarkan latar belakang tersebut di atas, pada penelitian ini akan membahas tentang perancangan komik 360 sebagai media informasi tentang pelecehan cat calling. Penelitian ini diharapkan dapat memberikan perspektif yang baru dalam penggunaan media yang dapat menyampaikan informasi serta meningkatkan kepekaan masyarakat tentang kejadian yang dihadapi oleh perempuan di jalanan serta tempat umum berkaitan dengan isu kekerasan seksual cat calling.

\section{METODE PERANCANGAN}

Perancangan komik 360 bersifat searah dan penyelesaian tahap-tahap sebelumnya akan diperlukan sebelum memulai tahap selanjutnya. Tahapan perancangan tersebut dapat dilihat pada Gambar 1 


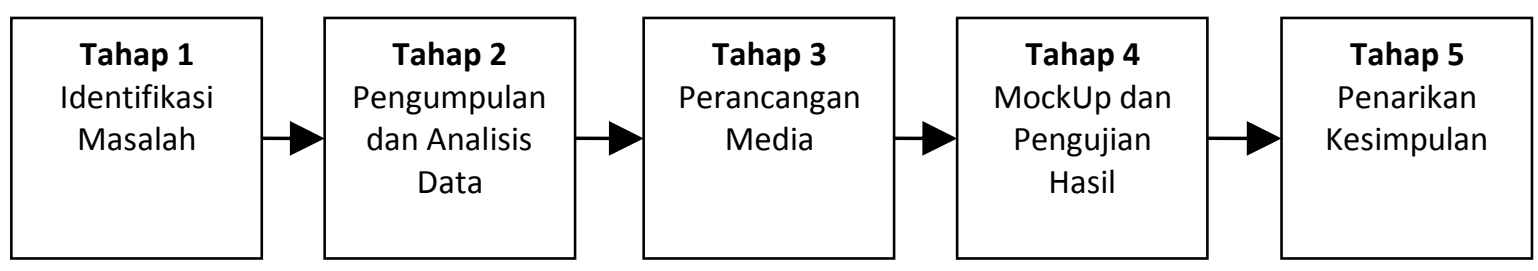

Gambar 1. Tahapan perancangan

[Sumber: Penulis]

Tahap pertama yang dilakukan adalah mengamati fenomena sosial yang berkaitan dengan cat calling dan media kampanye sosial yang ada selama ini. Hasil dari identifikasi masalah adalah masih kurangnya media yang dapat mendukung kampanye sosial mengenai kekerasan seksual terhadap wanita khususnya secara verbal dalam bentuk cat calling. Media yang ada belum dapat memberikan perlindungan terhadap korban kekerasan seksual dan belum dapat memberikan visualisasi secara netral.

Tahap kedua adalah tahap pengumpulan dan analisis data. Dalam tahap ini dilakukan pengumpulan data yang akan digunakan untuk perancangan. Untuk itu, dilakukan pengumpulan referensi gambar mengenai lingkungan jalanan dan fasilitas umum yang menjadi tempat terjadinya pelecehan seksual dalam bentuk cat calling. Selain itu, referensi gambar yang dikumpulkan menampilkan ciri khas lingkungan jalanan di Indonesia. Referensi gambar tersebut dapat dilihat pada Gambar 2.

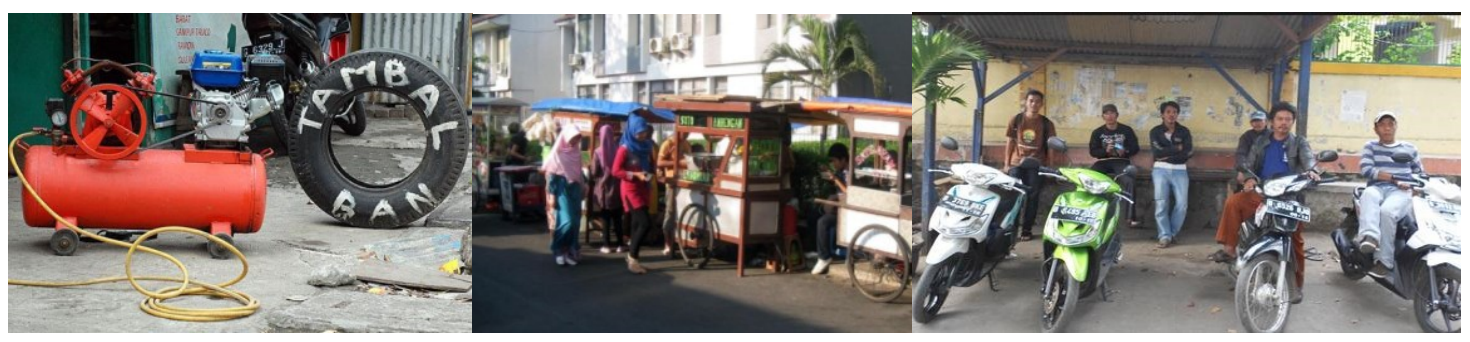

Gambar 2. Referensi lingkunan jalanan di Indonesia [Sumber: Penulis]

Tahap ketiga adalah perancangan komik 360 sebagai media kampanye tentang cat calling. Tahap perancangan dilakukan melalui tiga proses yaitu pra produksi, produksi dan pasca produksi. Proses pra produksi meliputi persiapan ide dan konsep, pembuatan deskripsi, alur cerita, serta sketsa. Ide dan konsep yang dikembangkan dalam komik 360 ini adalah gambaran secara visual tentang pelecehan yang diterima oleh perempuan sehari-hari saat berjalan di jalan umum yang seharusnya tidak terjadi. Deskripsi dan alur cerita yang disusun adalah sebagai berikut.

Jalan umum atau trotoar merupakan akses mobilitas yang sering digunakan oleh masyarakat. Namun bagi perempuan, berjalan di jalan umum juga membawa ancaman bagi keamanan dan kenyamanannya. Situasi yang terhampar di sekitar korban adalah sebuah jalan umum di Indonesia yang sibuk. Hari masih siang, beberapa orang lalu lalang di trotoar. Di sisi dalam trotoar berjejer pangkalan ojek dan area yang 
dialihfungsikan sebagai tempat usaha pedagang kaki lima serta tukang tambal ban. Badan jalan yang berhimpit langsung dengan trotar dipenuhi oleh motor yang parkir. Berbagai celotehan yang merendahkan serta siulan dan panggilan yang tidak diinginkan di tujukan pada korban. Beberapa orang berusaha menegur pelaku, ada juga yang berpikir untuk tidak ikut-ikutan dan memilih diam.

Berdasarkan deskripsi dan alur cerita yang telah disusun sebelumnya, dibuatlah sketsa elemen yang akan muncul di dalam komik 360. Selain sketsa elemen, dibuat juga sketsa panorama dan keadaan yang ada didalam komik. Sketsa panorama kemudian dipadukan dengan gambar elemen yang telah dibuat sehingga menjadi sketsa komik yang lengkap. Sketsa komik merupakan hasil akhir pada proses pra produksi. Selanjutnya, proses produksi dapat dimulai. Proses produksi diawali dengan pemberian warna pada sketsa komik. Teknik pewarnaan yang digunakan adalah teknik pewarnaan cat air.

Tahap berikutnya adalah memberikan dialog kedalam komik. Dialog disisipkan dengan menggunakan tanda balon teks. Dialog yang merupakan tindak pelecehan cat calling antara lain: "hai cantik, mau kemana?", "cewek...", "baju hitam, nengok dong", "cewek, sendirian aja, nih? Mau ditemenin, nggak?", "ih, sombong banget, sih?", dan "senyum dong.".

Proses selanjutnya adalah proses pasca produksi. Proses paska produksi terdiri atas pemberian metadata 360 kedalam file komik sehingga saat diunggah ke media sosial, media sosial akan mengenali jenis file 360 dan dapat ditampilkan dengan format 360 . Setelah pemberian metadata 360 ke dalam komik, komik diunggah ke media sosial yang telah mendukung jenis file 360 yaitu Facebook dan Youtube.

\section{HASIL DAN PEMBAHASAN}

Dari perancangan yang telah dilakukan, didapat hasil dari identifikasi masalah berupa kurangnya media kampanye tentang pelecehan seksual verbal berupa cat calling yang tidak hanya informatif tapi juga memberikan gambaran secara netral tentang kejadian pelecehan. Dari masalah tersebut, dikumpulkan data berupa referensi gambar lingkungan dan fasilitas umum tempat kejadian pelecehan seksual, dalam hal ini adalah jalanan umum. Kemudian dilakukan perancangan berupa komik 360 itu sendiri.

Hasil pertama adalah sketsa setiap elemennya yang dihasilkan dari data berupa gambar referensi dan observasi lapangan. Sketsa elemen dapat dilihat pada Gambar 3. 

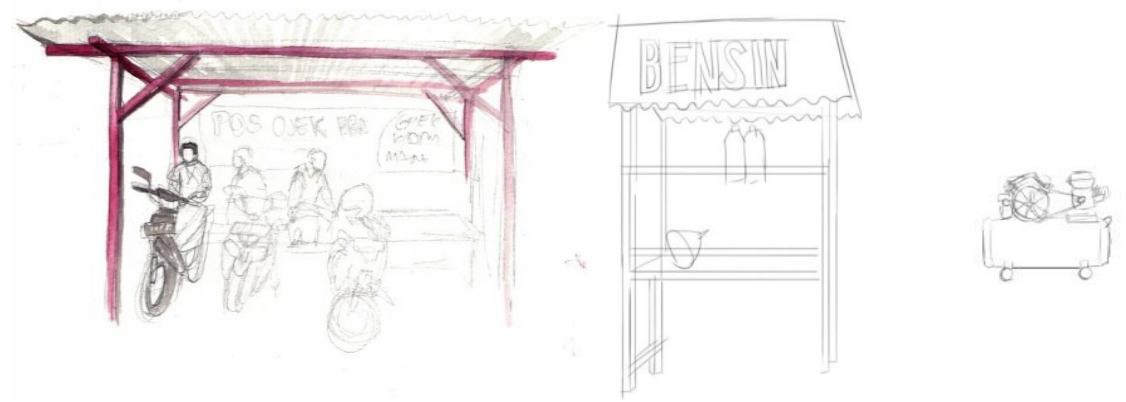

Gambar 3. Sketsa elemen

[Sumber: Penulis]

Hasil yang kedua adalah sketsa panorama. Sketsa panorama pada komik 360 berbeda dengan panorama pada umumnya. Hal tersebut dikarenakan, panorama harus dapat merepresentasikan lingkungan sekitar dan bersifat seamless. Panorama juga harus memperhatikan posisi sudut pandang pengguna. Sketsa panorama dapat dilihat pada Gambar 4.

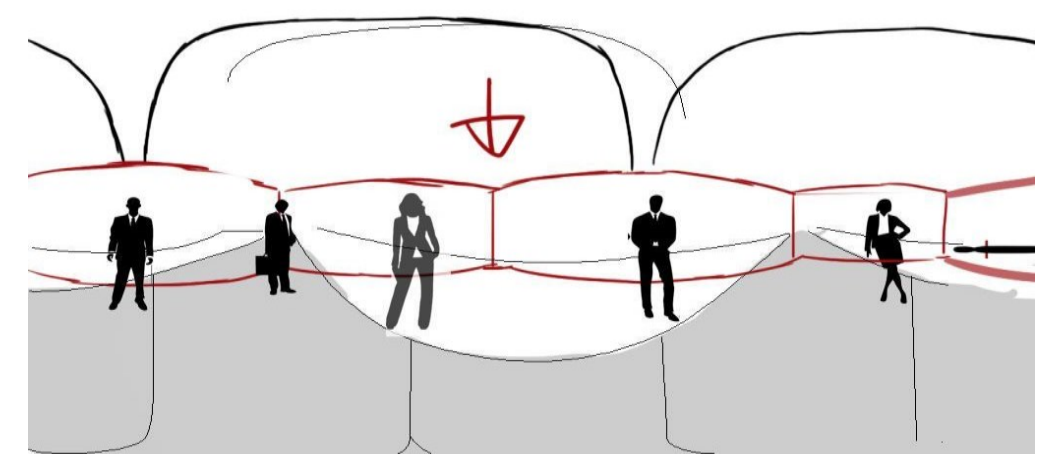

Gambar 4. Sketsa panorama

[Sumber: Penulis]

Berdasarkan sketsa elemen dan sketsa panorama, dibuatlah sketsa lingkungan yang merupakan dunia di dalam komik 360. Sketsa komik dapat dilihat pada Gambar 5.

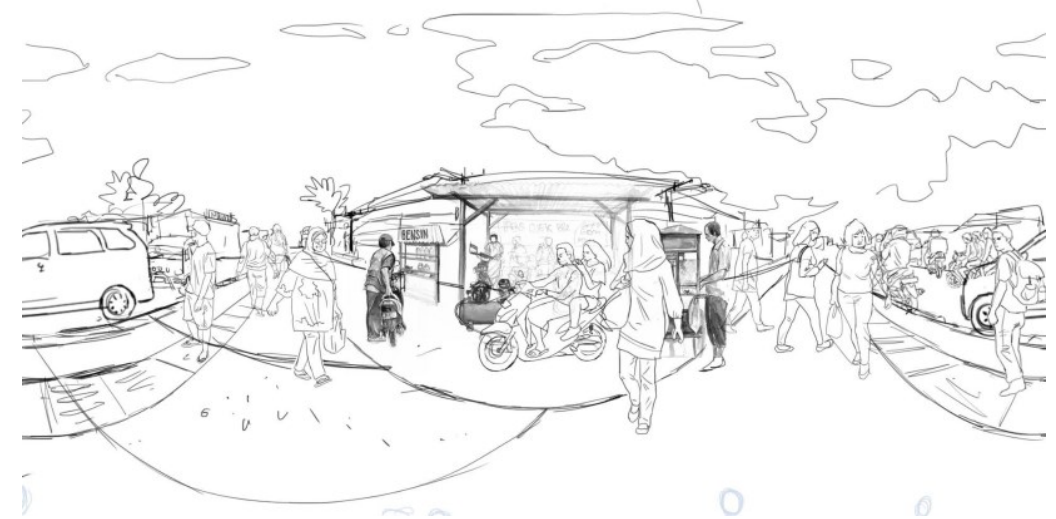

Gambar 5. Sketsa komik

[Sumber: Penulis] 
Sketsa tersebut diberi warna dengan gaya pewarnaan cat air. Hasil pewarnaan sketsa komik dapat dilihat pada Gambar 6.

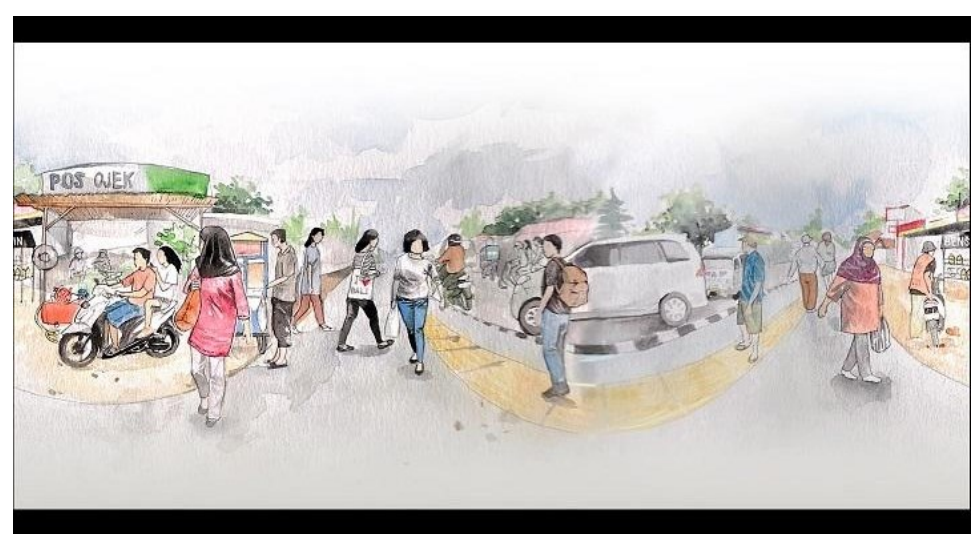

Gambar 6. Hasil pewarnaan sketsa komik [Sumber: Penulis]

Elemen lain dari komik 360 adalah balon teks. Dialog diketik dengan menggunakan jenis teks Roof Runner berukuran 30 pt. Jenis teks yang digunakan termasuk dalam kategori sans serif yang merupakan jenis teks tanpa kait. Pemilihan jenis teks didasari oleh karakteristik jenis teks yang modern dan sering digunakan dalam komik. Jenis teks Roof Runner dapat dilihat pada Gambar 7. Dialog balon kata disisipkan kedalam gambar komik dengan menggunakan efek fade in dan fade out. Efek tersebut merupakan efek animasi dimana kemunculan objek muncul secara perlahan dan menghilang kembali.
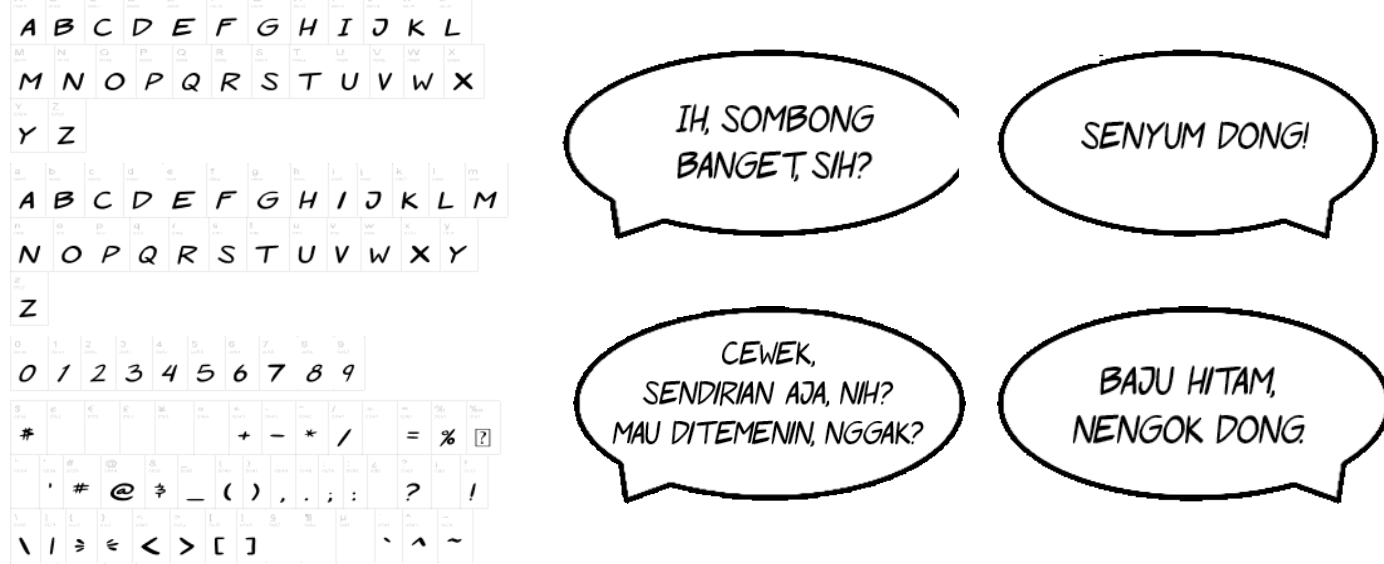

(C)

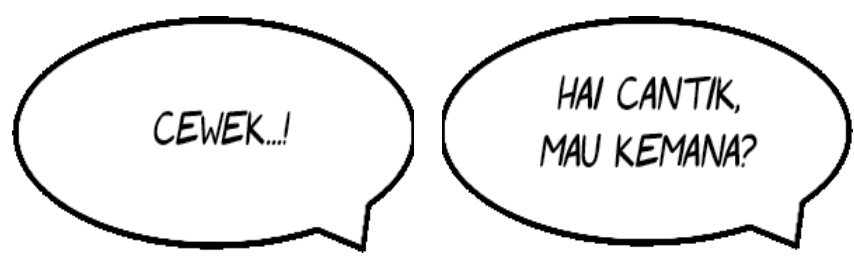

Gambar 7. (kiri) Jenis teks Roof Runner dan (kanan) dialog balon teks

[Sumber: Penulis] 
Tampilan hasil perancangan komik 360 dapat dilihat pada bagian atas Gambar 8 sedangkan kemunculan balon teks dalam komik 360 dapat dilihat pada bagian bawah Gambar 8.
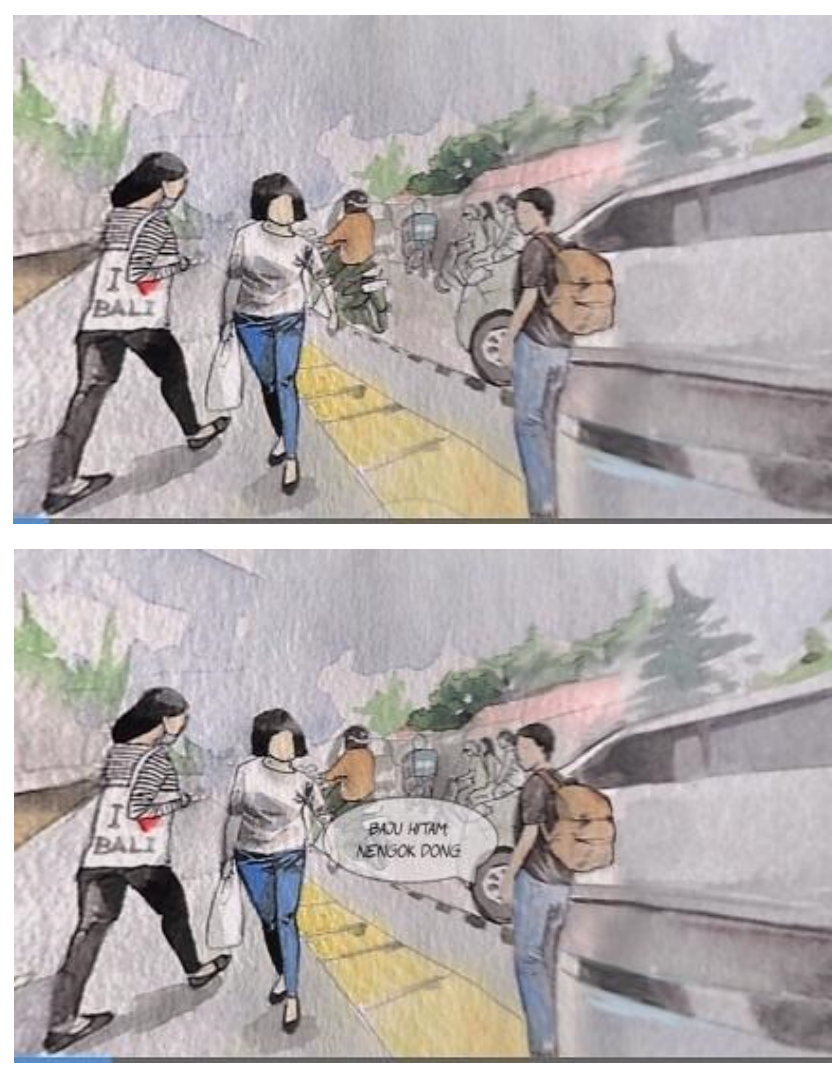

Gambar 8. (atas) Tampilan awal komik 360 dan (bawah) kemunculan balon teks pada komik 360 [Sumber: Penulis]

Penyebaran informasi dilakukan dengan cara mengunggah komik 360 ke media sosial yaitu Facebook dan Youtube dimana kedua media sosial tersebut dapat menampilkan foto dan video 360. Pengaplikasian komik 360 pada media sosial dapat dilihat pada Gambar 9.

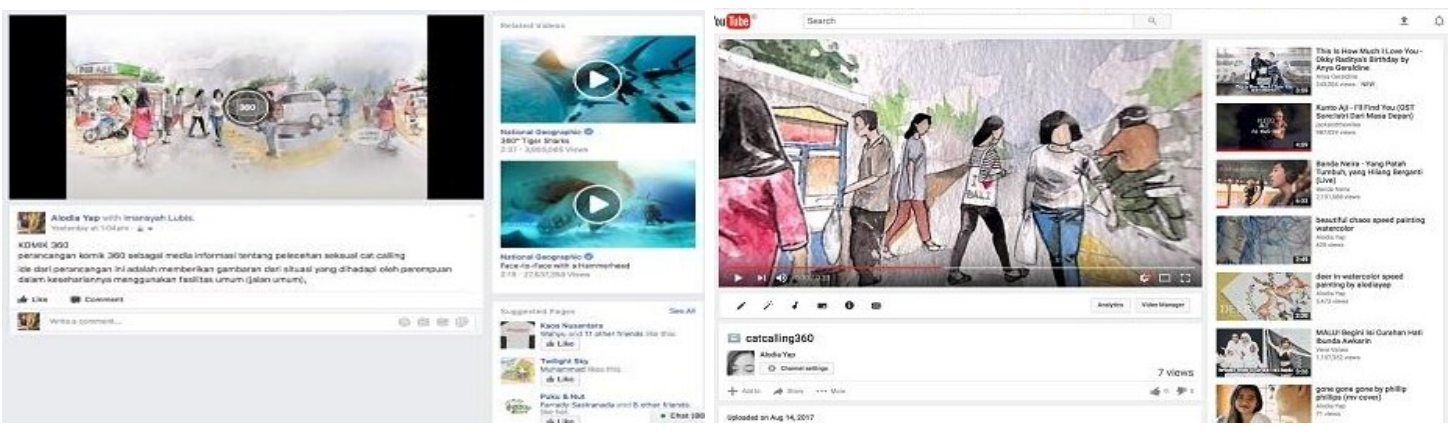

Gambar 9. Pengaplikasian komik 360 pada Facebook dan Youtube

[Sumber: Penulis] 
Hasil perancangan komik 360 sebagai media informasi tentang pelecehan seksual cat calling diujikan kepada 5 orang mahasiswa jurusan Desain Komunikasi Visual dan Komunikasi yang berusia 18-23 tahun. Kelima orang tersebut berpendapat bahwa komik 360 tersebut sudah cukup baik dalam memberikan informasi mengenai kekerasan seksual cat calling dengan menarik. Selain itu, responden dapat dengan mudah menangkap dan memahami isi pesan yang terkandung dalam komik 360 tersebut.

Pengujian kedua dilakukan kepada Aji Prasetyo selaku komikus. Menurut Aji Prasetyo, komik 360 ini sudah sangat baik ditinjau dari sisi visual dan kualitas gambar. Namun dapat ditingkatkan lagi dengan cara menggali lebih dalam efek psikologis pelaku maupun korban cat calling sehingga pembaca komik dapat mengalami pengalaman emosional yang lebih bersifat personal.

Pengujian ketiga dilakukan kepada Ignatia Gloria selaku aktivis perempuan yang memiliki perhatian terhadap isu kekerasan seksual. Materi yang diujikan berupa konsep dan ide tentang cat calling yang diangkat dalam perancangan ini. Menurut Ignatia Gloria, hasil perancangan ini mampu menjadi media untuk menyuarakan kegelisahan terkait perilaku kekerasan seksual terhadap perempuan. Karya ini mampu menyajikan sebuah realitas yang dekat dengan kehidupan perempuan sehari-hari. Cara penyajiannya membuat seolah-olah pembaca sedang mengalami peristiwa cat calling, yang seringkali dianggap biasa saja oleh mayoritas masyarakat. Komik 360 ini sangat layak untuk dipublikasikan sebagai sebuah media kampanye anti pelecehan seksual.

Berdasarkan pengujian-pengujian yang telah dilakukan, maka dapat diperoleh hasil analisis pengujian yaitu komik 360 yang telah dihasilkan memiliki visualisasi yang menarik dan dapat membantu pengguna untuk memahami pesan yang ada secara mudah. Walaupun masih dianggap kurang dapat memberikan pengalaman emosional yang bersifat personal, namun komik 360 ini telah layak untuk dipergunakan sebagai salah satu media alternatif dalam melakukan kampanye sosial tentang anti pelecehan seksual terhadap perempuan.

\section{KESIMPULAN}

Media informasi tentang pelecehan cat calling dengan menggunakan komik 360 merupakan jenis media baru yang mengkombinasikan teknologi 360 dengan media komik sehingga menimbulkan kesan yang berbeda dalam menikmatinya. Komik 360 tersebut dapat dijadikan sebagai media untuk menyampaikan informasi tentang pelecehan seksual secara verbal terhadap perempuan di jalanan, khususnya di Indonesia. Media ini dapat dijadikan media alternatif bagi gerakan kampanye social tentang anti kekerasan seksual terhadap perempuan karena dapat menyajikan secara visual kondisi lingkungan tempat terjadinya kekerasan seksual. Untuk penelitian selanjutnya disarankan untuk dapat menambahkan fitur dalam skema panorama dan menggambarkan keadaan lingkungan yang lebih beragam. Di samping itu, penelitian juga dapat dikembangkan dengan lebih menitikberatkan pada penyampaian sisi emosional korban maupun pelaku kekerasan seksual. 


\section{DAFTAR PUSTAKA}

Adyatama, E. 2017. Women's March Jakarta Mengusung 8 Tuntutan untuk Pemerintah. (Update 4 Maret 2017) URL: https://tempo.co/read/news/2017/03/04/173852617/womens-marchjakarta-mengusung-8-tuntutan-untuk-pemerintah [Diakes pada 15 Maret 2017]

Dailymail.co.uk. 2015. Aspiring actress who was paid to star in 'Walking in NYC as a Woman' cat-calling video files $\$ 500 \mathrm{~K}$ lawsuit against the director for 'violating her civil rights'. (Update 15 Juli 2015) URL: http://www.dailymail.co.uk/news/article-3161795/Aspiring-actress-paid-starWalking-NYC-Woman-cat-calling-video-files-500K-lawsuit-against-directorviolating-civil-rights.html [Diakses pada 15 Maret 2017]

Etherington, D. 2015. Facebook to Support Spherical Video in News Feed and Oculus. (Update 25 Maret 2015) URL: https://techcrunch.com/2015/03/25/facebookto-support-spherical-video-in-news-feed-and-oculus/ [Diakses pada 15 Desember 2016]

Johana, M. \& Widiyanti, A. 2007. Komik Sebagai Media Pengajaran Bahasa yang Komunikatif Bagi Siswa SMP. Lembaran IImu Pendidikan Vol. 36 No. 1 hal. 2834.

Kapriani, D. R. \& Lubis, D. P. 2014. Efektivitas Media Sosial untuk Gerakan Sosial Pelestarian Lingkungan. Jurnal Sosiologi Pedesaan, Vol. 2 No. 3 hal. 160-170.

Komnas Perempuan. 2009. Perempuan dalam Jeratan Impunitas: Pelanggaran dan Penanganan, Dokumentasi Pelanggaran HAM Perempuan Selama Konflik Bersenjata di Poso 1998-2005. Jakarta: Komnas Perempuan.

Laksono, A. 2004. Comic Strips: Media Kritik Sosial. Jurnal Sastra dan Bahasa, Vol 2 No. 2 hal. 183-193.

McCloud, S. 2001. Understanding Comics (Memahami Komik). Jakarta: Kepustakaan Populer Gramedia.

Offerman, L. R. \& Malamut, A. B. 2002. When Leaders Harash: The Impact of Target Perception of Organization Leadership and Climate in Harassment Reporting and Outcomes. Journal of Applied Psychology, 87(5) pp. 885-893.

Qubicle.id. 2016. Revolusi KOMIK 360 di AngkRingan Malioboro!. (Update Agustus 2016) URL: https://qubicle.id/story/revolusi-komik-360-di-angkringanmalioboro [Diakses pada 15 Desember 2016]

Saputro, G. E., Haryadi, T., \& Yanuarsari, D. H. 2016. Perancangan Purwarupa Komik Interaktif Safety Riding Berkonsep Digital Storytelling. ANDHARUPA, 2(2), 195206.

Wattie, A. M. 2002. Kekerasan terhadap Perempuan di Ruang Publik: Fakta, Penanganan dan Rekomendasi. Yogyakarta: Pusat Studi Kebijakan dan Kependudukan \& Ford Foundation. 